\title{
UPAYA MENGENALKAN ASMAUL HUSNA MELALUI METODE BERCERITA PADA ANAK USIA DINI
}

\author{
Zulfitria \\ Nur Budhi Cahyani \\ fzulfitria@umj.ac.id \\ Jurusan Teknologi Pendidikan, Fakultas IImu Pendidikan, Universitas Muhammadiyah Jakarta, Jalan \\ KH. Ahmad Dahlan Cireundeu-Ciputat Timur,15419 \\ Zainal Arif \\ zarifpambon@gmail.com \\ Pendidikan Agama Islam, Fakultas Agama Islam, Universitas Muhammadiyah Tangerang, \\ Jln. Perintis Kemerdekaan I Babakan No.33 Tangerang-Banten
}

\begin{abstract}
Asmaul Husna can be interpreted as the names of Allah SWT who are good, noble, and great. The introduction of Asmaul Husna can be started when the child begins to enter early childhood education. But the ways are different with adults. Early childhood education must be fun, with the concept of playing or with stories that are easily digested by early childhood, so that children are happy and not burdened. The introduction of Asmaul Husna in early childhood can be done by using the right storytelling method that is in accordance with the level of understanding of early childhood. The choice of media and storytelling techniques also affects children's understanding. The more interesting the methods, techniques and media used, the more students will understand the Asmaul Husna delivered. This research is a classroom action research (CAR) using two cycles for Kindergarten A students (aged 4-5 years). The results of this study showed an increase in the ability to listen to stories, the ability to understand the essence of the story and Asmaul Husna and the understanding of the language used so that it can be concluded that the introduction of Asmaul Husna with the storytelling method is easily understood by early childhood.
\end{abstract}

Keywords: Asmaul Husna, storytelling, early childhood

\begin{abstract}
ABSTRAK
Asmaul Husna dapat diartikan sebagai nama-nama Allah SWT yang baik, mulia, dan agung. Pengenalan Asmaul Husna bisa dimulai saat anak mulai memasuki pendidikan usia dini. Namun cara-caranya berbeda dengan orang dewasa. Pendidikan anak usia dini harus menyenangkan, dengan konsep bermain atau dengan cerita-cerita yang mudah dicerna oleh anak usia dini, sehingga anak senang dan tidak terbebani. Pengenalan Asmaul Husna pada anak usia dini dapat dilakukan dengan menggunakan metode bercerita yang tepat yang sesuai dengan tingkat pemahaman anak usia dini. Pemilihan media dan teknik bercerita juga mempengaruhi pemahaman anak. Semakin menarik metode, teknik dan media yang digunakan maka akan siswa akan makin paham dengan asmaul husna yang disampaikan. Penelitian ini merupakan penelitian tindakan kelas (PTK) dengan menggunakan dua siklus pada siswa TK A (usia 4-5 tahun). Hasil penelitian ini terdapat peningkatan kemampuan mendengarkan cerita, kemampuan memahami inti cerita dan asmaul husna serta pemahaman bahasa yang dipakai sehingga dapat disimpulkan bahwa pengenalan asmaul husna dengan metode bercerita mudah dipahami oleh anak usia dini.
\end{abstract}


Kata Kunci: Asmaul husna, Bercerita, Anak usia dini

\section{A. Pendahuluan}

Rukun Iman yang pertama adalah percaya kepada Allah SWT. Percaya artinya meyakini tentang keberadaan Allah SWT. Untuk meyakini dan mempercayai Allah SWT Allah SAW, manusia perlu mengenal Allah. Cara untuk mengenal Allah SWT adalah dengan mengenal nama-namanya. Namanama Allah SWT terdiri 99, bahkan ada yang menyebutkan lebih dari 99. Nama-nama Allah SWT dikenal dengan nama Asmaul Husna. Asmaul Husna adalah nama-nama Allah SWT yang baik. Berzikir dan berdoa dengan Asmaul Husna adalah amalan ibadah yang diperintahkan Allah, bahkan dapat menjadi salah satu sarana terkabulnya doa. Setiap manusia sebagai mahluk beriman harus mengenal Allah SWT sebagai Tuhannya. Pengenalan Asmaul Husna merupakan sarana untuk mengenal Allah SWT dengan sifat maha segala-galanya.

Pengenalan Asmaul Husna bisa dimulai saat anak mulai memasuki pendidikan usia dini. Namun cara-caranya berbeda dengan orang dewasa. Pendidikan anak usia dini harus menyenangkan, dengan konsep bermain atau dengan cerita-cerita yang mudah dicerna oleh anak usia dini, sehingga anak senang dan tidak terbebani. Kenyataan di lapangan karena banyaknya kemampuan akademis yang harus dikejar kegiatan jadi membosankan. Beberapa identifikasi masalah penelitian sebagai berikut: 1) Bagaimana cara mengenalkan Asmaul Husna pada anak usia dini. 2) Apakah metode bercerita dapat digunakan untuk mengenalkan Asmaul Husna pada anak usia dini. 3) Bagaimana cara mengenalkan Asmaul Husna melalui metode bercerita pada anak usia dini. Dari identifikasi masalah tersebut, peneliti merumuskan penelitian sebagai berikut: "Bagaimana cara mengenalkan asmaul husna melalui metode bercerita pada anak usia dini?

\section{B. Metode Penelitian}

Penelitian ini berbentuk penelitian tindakan kelas (PTK). Penelitian tindakan kelas adalah penelitian praktis untuk memperbaiki pembelajaran dikelas. Peneliti melakukan data studi pustaka dijadikan diambil dari buku-buku yang berhubungan dengan asmaul husna, pendidikan anak usia dini dan metode bercerita/dongeng. Kemudian melakukan eksperimen terhadap siswa TK A (usia 4-5 tahun) di TK Hamzah. Waktu penelitian ini adalah bulan Juli sd September 2018. Tujuan penelitian ini adalah untuk mengetahui cara pengenalan Asmaul Husna untuk anak usia dini dan mengetahui pemanfaatan metode bercerita untuk anak usia dini dalam pengenalan Asmaul Husna

\section{Hasil Penelitian dan Pembahasan \\ Hakekat Asmaul Husna}

Kata Asmaul Husna terdiri dari dua kata yaitu asma' dan husna. Asma' adalah jamak dari kata ism yang berarti nama. Kata ism juga satu akar dengan kata sumuw yang berarti tinggi. Sedang husna adalah bentuk mu'annats dari kata ahsan yang berarti baik. Dengan demikian, dapat diartikan bahwa al Asmaul Husna adalah nama-nama yang baik, mulia, dan agung ${ }^{1}$. Kata Asmaul Husna secara tegas disebutkan dalam Al Qur'an sebanyak 4 kali, yaitu:

Pertama, dalam Alquran Surat Al A'raf: 180, berbunyi:

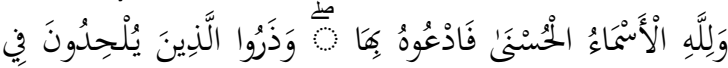

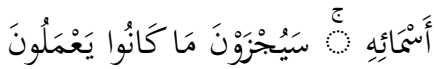

"Hanya milik Allah al Asmaul Husna, maka bermohonlah kepada-Nya dengan menyebut al Asmaul Husna itu dan tinggalkanlah orang-orang yang menyimpang dari kebenaran dalam

${ }^{1}$ El Qudsy, Hasan. 2014, The Miracle of 99 Asmaul Husna. Surakarta: Ziyad Book. 
(menyebut) nama-nama-Nya. Nanti mereka akan mendapat balasan terhadap apa yang telah mereka kerjakan."

Kedua, dalam Alquran Surat Al Isra: 110, berbunyi:

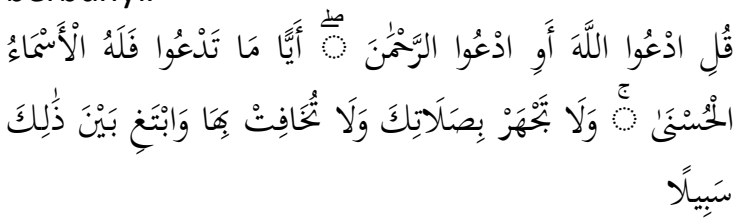

"Katakanlah: "Serulah Allah atau serulah Ar Rahman. Dengan nama yang mana saja kamu seru, Dia mempunyai Asmaul Husna (namanama terbaik). Dan janganlah kamu merasakan suaramu dalam shalatmu dan janganlah pula merendahkannya dan carilah jalan tengah di antara kedua itu."

Ketiga, dalam Alquran Surat Thaha: 8, berbunyi:

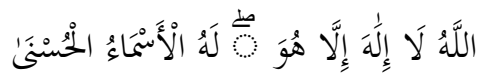

"Dialah Allah tidak ada ilah (yang berhak disembah) melainkan Dia. Dia mempunyai al Asmaul Husna (nama-nama yang baik)"

Keempat, dalam Alquran Surat Al Hasyr: 24, berbunyi:

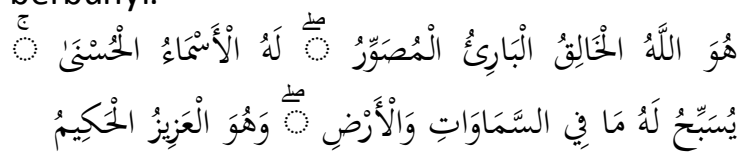
"Dialah Allah Yang Menciptakan, Yang Mengadakan, Yang Membentuk Rupa, Yang Mempunyai al Asmaul Husna. Bertasbih kepada -Nya apa yang ada di langit dan bumi. Dan dialah Yang Maha Perkasa lagi Maha Bijaksana."

Dari keempat ayat tersebut jelaslah dalam Al Qur'an Allah memiliki nama-nama Allah yang baik dengan segala keistimewaannya. Rasulullah SAW bersabda seperti yang diriwayatkan oleh ash Shaduq di Kitab At Tauhid, Allah SWT memiliki Sembilan puluh Sembilan nama. Barang siapa berdoa kepada Allah dengan menyebut nama-nama tersebut, niscaya Allah SWT akan mengabulkannya. Barang siapa menghafal nama-nama itu, niscaya dia akan masuk surga. ${ }^{2}$. Asmaul Husna berjumlah 99. Hal ini berdasarkan HR. Bukhari "Allah memiliki Sembilan puluh Sembilan nama, seratus kurang satu. Tiada seorang menghafalnya melainkan ia akan masuk surga. Dan dia adalah witir (ganjil) dan menyukai yang ganjil.

HR Tarmidzi meriwayatkan Asmaul Husna terdiri dari 99 yaitu: Allah, Ar Rahman, Ar Rahim, Al Malik, Al Quddus, As Salam, Al Mu'min, Al Muhaimin, Al Aziz, Al Jabbar, Al Mutakabbir, Al Khaliq, Al Bari', Al Mushawwir, Al Ghaffar, Al Qahhar, Al Wahhab, Ar Razzaq, Al Fattah, Al Alim, Al Qabidh, Al Basith, Al Khafid, Ar Rafi, Al Muiz, Al Mudzil, As Sami', Al Bashir, Al Hakam, Al Adl', Al Lathif, Al Khabir, Al Halim, Al Azhim, Al Ghofur, Asy Syakur, Al Aliyy, Al Kabir, Al Hafizh, Al Muqit, Al Hasib, Al Jalil, Al Karim, Ar Raqib, Al Mujib, Al Wasi', Al Hakim, Al Wadud, Al Majid, Al Baits, Asy Syahid, Al Haqq, Al Wakil, Al Qawiyy, Al Matin, Al Waliy, Al Hamid, Al Muhshiy, Al Mubdi', Al Muid, Al Muhyi, Al Mumit, Al Hayy, Al Qayyum, Al Wajid, Al Majid, Al Wahid, Ash Shamad, Al Qadir, Al Muqtadir, Al Muqaddim, Al Mu'akhir, Al Awwal, Al Akhir, Azh Zhahir, Al Bathin, Al Wali, Al Muta'ali, Al Barr, At Tawwab, Al Muntaqim, Al Afuw, Ar Rauf, Malik al Mulk, Dzul Jalali wal Ikram, Al Jami' Al Ghaniy, Al Mughniy, Al Mani' Ad Dhar, An Nafi' An Nur, Al Hadi, Al Badi', Al Baqi, Al Warits, Ar Rasyid, Ash Sabur ${ }^{3}$.

\section{Hakekat Metode Bercerita}

Menurut Gunarti dkk (2008) bercerita adalah menceritakan atau membacakan cerita yang mengandung nilai-nilai pendidikan, melalui cerita daya imajinasi anak dapat ditingkatkan, karena bercerita merupakan suatu kegiatan yang dilakukan seseorang untuk menyampaikan suatu pesan, informasi atau sebuah dongeng belaka, yang bisa

${ }^{2}$ Arabi, Ibnu. 2015, Rahasia Asmaul Husna: Mengungkap 99 Nama Allah. Jakarta: Turos.

${ }^{3}$ El Qudsy, Hasan. 2014, The Miracle of 99 Asmaul Husna. Surakarta: Ziyad Book. 
dilakukan secara lisan atau tertulis ${ }^{4}$. Metode bercerita adalah metode yang mengisahkan suatu peristiwa atau kejadian kepada peserta didik. Kejadian atau peristiwa tersebut disampaikan kepada peserta didik melalui tutur kata, ungkapan dan mimik wajah yang unik. Pendapat lain menyebutkan metode bercerita merupakan metode pembelajaran yang menggunakan teknik guru bercerita tentang suatu legenda, dongeng, mitos atau suatu kisah yang di dalamnya diselipkan pesan-pesan moral atau intelektual tertentu ${ }^{5}$.

Bercerita dapat disertai gambar maupun dalam bentuk lainnya seperti: panggung boneka. Cerita sebaiknya diberikan secara menarik dan membuka kesempatan bagi anak untuk bertanya dan memberikan tanggapan setelah cerita selesai. Ada berbagai manfaat bercerita untuk anak, yaitu: sebagai alat pendidikan budi pekerti yang paling mudah dicerna anak, dapat diintegrasikan dengan keterampilan lain, yaitu berbicara, membaca, menulis dan menyimak, dapat mengembangkan kemampuan bersimpati dan berempati, dapat memberi pelajaran cara menyingkapi masalah, mengajarkan nilai-nilai sosial, mengenalkan budaya, mendekatkan anak secara emosional kepada orang tua, menumbuhkan rasa ingin tahu, meningkatkan daya imajinatif. Anak-anak cenderung meniru apa yang mereka dengar, lihat dan tonton. Dongeng bisa menjadi metode yang sangat efektif untu memasukkan nilai kebaikan pada diri anak dalam sebuah kemasan menarik. Dongeng dapat merubah konsep yang abstrak menjadi konsep yang kongkrit yang mudah dipahami anak. Beberapa tips mendongeng yang baik, misalnya pendongeng menampilkan ceritanya dengan ekspresif dan energik serta menguasai cerita tersebut, cerita bervariasi, memiliki pesan positif, sesuai dengan usia anak, menggunakan alat peraga,

${ }^{4}$ Gunarti, Linda.dkk 2008. Metode Pengembangan Perilaku dan Kemampuan Dasar Anak Usia Dini, Jakarta: Ute.

${ }^{5}$ Fadlilah,Muhammad, 2012, Desain Pembelajaran PAUD: Tinjauan Teoritik dan Praktik, Yogyakarta: Ar Ruzz Media menggunakan mimik dan intonasi suara yang tepat, melibatkan anak dalam dongeng, dan tentukan waktu yang tepat untuk mendongeng ${ }^{6}$. Metode Bercerita memiliki banyak tujuan, diantaranya:

a. Mengembangkan kemampuan bahasa, yaitu kemampuan menyimak, kemampuan dalam berbicara, serta kemampuan menambah kosa kata yang dimilikinya.

b. Mengembangkan kemampuan berpikirnya karena dengan bercerita anak diajak untuk memfokuskan perhatian dan berfantasi mengenai jalan cerita serta mengembangkankemampuan berpikir secara simbolik.

c. Menanamkan pesan-pesan moral yang terkandung dalam cerita yang akan mengembangkan kemampuan moal dan agama, misalnya konsep benar salah atau konsep kebutuhan.

d. Mengembangkan kepekaan social-emosi anak tentang hal-hal yang terjadi di sekitarnya melalui tuturan cerita yang disampaikan.

e. Melatih daya ingat atau memori anak untuk menerima dan menyimpan informasi melalui tuturan peristiwa yang di sampaikan.

f. Mengembangkan potensi kreatif anak melalui keragaman ide cerita yang dituturkan. ${ }^{7}$

Metode bercerita merupakan cara bertutur untu menyampaikan sesuatu secara lisan dengan mengisahkan perbuatan, pengalaman serta suatu kejadian yang benarbenar terjadi ataupun merupakan karangan (dongeng), yang mengandung nilai-nilai kehidupan yang dapat diresapi serta mudah dicerna oleh anak-anak. Cerita memiliki banyak manfaat, karena biasanya. Metode

${ }^{6} \mathrm{Al}$ Qudsy, Muhaimin dan Ulfah Nurhidayah, 2010, Mendidik Anak Lewat Dongeng, Yogyakarta: Madania

${ }^{7}$ Montolulu, dkk, 2008. Bermain dan Permainan Anak. Jakarta: Ute. 
bercerita memberikan sumbangan besar pada seluruh aspek perkembangan anak usia dini.

\section{Hakekat Anak Usia Dini}

Menurut Piaget dalam Santrock (2009) mengemukakan empat tahap perkembangan kognitif pada anak usia dini, diantaranya:

1) Sensori motorik (0-2 tahun)

Tahap perkembangan sensori motorik anak mengembangkan kemampuan untuk mengorganisasikan dan mengkoordinasikan sensasi dan persepsi dengan gerakan-gerakan dan tindakantindakan fisik. Tahap pemikiran tersebut adalah pra operasional, pada tahap ini konsep yang stabil dibentuk penalaran mental muncul, egosentrisme mulai kuat dan kemudian lemah

2) Pra operasional (2-7 tahun)

Pada pra operasional anak belum berpikir secara operasional, tahapan ini sangat terorganisasi dan sesai dengan aturanaturan dan prinsip-prinsip logika tertentu. Tahap pra operasional bukan hanya yang berbentuk konkret tapi juga formal. Pemikiran pra operasional adalah awal kemampuan untuk melaksanakan pada tingkat pemikiran apa yang telah dilakukan di dalam prilaku.Tahap pra operasional dibagi ke dalam dua tahap yaitu sub tahap simbolis dan sub tahap pemikiran intuitif.

a) Sub tahap simbolis

Adalah sub tahap pertama pemikiran pra operasional yang terjadi kira-kira antara usia 2-4 tahun. Pada sub tahap ini anak-anak mengembangkan kemampuan untuk membayangkan secara mental suatu obyek yang tidak ada kemampuan untuk berpikir. Simbolis seperti ini disebut fungsi simbolis dan kemampuan itu mengembangkan

${ }^{8}$ Zulfitria1).Sriyanti Rahmatunnisa2).

Mutia Khanza. 2021. Penggunaan Metode Bercerita Dalam Pengembangan Kemampuan Kognitif Pada Anak Usia Dini. Jakarta: Yaa bunayya. secara cepat dunia mental anak. Anakanak pra sekolah tidak terlalu peduli akan realitas, gambar yang dibuatnya penuh khayalan dan daya cipta.

b) Sub tahap intuitif

Adalah sub tahap pemikiran pra operasional yang terjadi kira-kira antara usia 4-7 tahun. Pada tahap ini anak-anak mulai menggunakan penalaran dan ingin tahu jawaban atas semua bentuk pertanyaan. Pada tahap intuitif anak-anak usia muda tampaknya begitu yakin tentang pengetahuan dan pemahaman mereka, tetapi belum begitu sadar bagaimana mereka tahu apa yang mereka ketahui.

3) Operasi konkret (7-11 tahun)

Anak-anak sudah dapat memahami operasi logis dengan bantuan benda konkret. Kemampuan tersebut terwujud dalam memahami konsep kekekalan. Kemampuan untuk mengklafikasi dan seriasi mampu memandang suatu objek dari sudut pandang yang berbeda secara obyektif dan mampu berpikir reversibel.

4) Operasi formal (11 tahun- dewasa)

Anak-anak sudah mampu melakukan penalaran yang menggunakan hal-hal yang abstrak, sehingga penggunaan benda-benda konkret sudah tidak diperlukan lagi ${ }^{9}$. Anak usia dini berada pada usia 0-6 tahun. Mereka adalah kelompok anak yang berada dalam proses pertumbuhan dan perkembangan yang bersifat unik. Yaitu pola pertumbuhan dan perkembangan (koordinasi motorik halus dan kasar), intelegensia (daya pikir, daya cipta, kecerdasan emosi, dan kecerdasan spiritual), emosi sosial (sikap dan perilaku serta agama) bahasa dan komunikasi yang khusus sesuai dengan tingkat pertumbuhan dan perkembangan anak.

Anak mudah menyerap apapun yang dilihat, didengar dan dirasakan. Pemberian stimulus yang baik, khususnya dalam bidang

9 Santrock, John W. 2009. Life Span Development Perkembangan masa hidup. Jakarta. 
agama dan moral dapat menjadikan anak lebih religious dan cinta pada agama dan Tuhannya. Perasaan ruhaniah yang berkaitan dengan religious yaitu perasaan yang menyertai penghayatan keagamaan ukuran atau sumber perasaan ini adalah agama. Contohnya perasaan ikhlas, tawakal, dan lainlain ${ }^{10}$. Pengenalan Asmaul Husna pada anak usia dini dapat meningkatkan penghayatan agama, peningkatan nilai agama dan moral serta kematangan emosional. Prosedur pelaksanakan tindakan kelas dapat dilihat dalam bagan di bawah ini ${ }^{11}$ :

Sebelum memulai siklus I, peneliti mengadakan penelitian pra siklus untuk mengetahui pemahaman siswa terhadap materi asmaul husna. Dari jumlah siswa TK A sebanyak 16 orang, diketahui siswa dapat menghafal nama asmaul husna, namun siswa belum memahami arti asmaul husna tersebut.

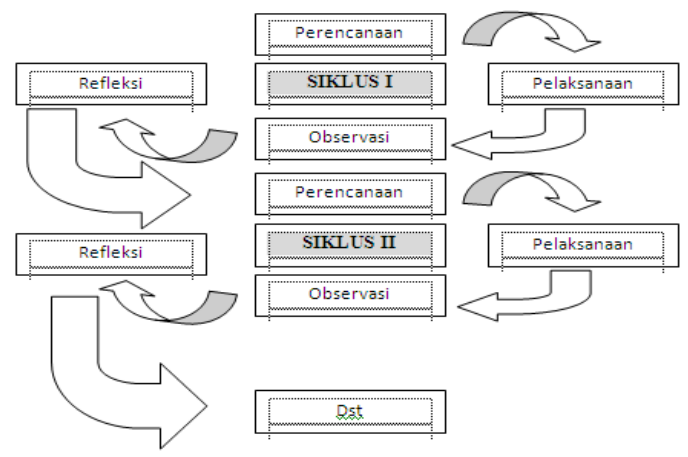

Gambar 1. Prosedur siklus penelitian

Siklus I:

Kegiatan pada siklus pertama diawali dengan membuat perangkat pembelajaran secara kolaboratif partisipatif antara guru dan peneliti. Kemudian membuat rencana kegiatan pembelajaran yang terdiri dari:

\footnotetext{
${ }^{10}$ Fadlilah,Muhammad, 2012, Desain Pembelajaran PAUD: Tinjauan Teoritik dan Praktik, Yogyakarta: Ar Ruzz Media.

11 Arikunto, Suharsimi, 2017, Penelitian Tindakan Kelas, Jakarta: Bumi Aksara
}

a. Perencanaan

Langkah-langkah yang harus dilakukan dalam tahap perencanaan oleh peneliti bersama guru menyiapkan perangkat pembelajaran berupa RPPM dan RPPH serta media bercerita. Media bercerita yang digunakan adalah kartu ukuran A4 berisi adegan gambar yang akan diceritakan. Cerita yang dipilih adalah cerita dalam Al Qur'an dan siroh Nabi yang isinya berkenaan dengan Asmaul Husna . Kemudian dilanjutkan dengan menyiapkan instrument test berupa soal test unjuk kerja penilaiannya. Instrumen non test berupa lembar panduan observasi untuk mengamati aktifitas siswa dan kinerja guru dalam proses pembelajaran.

b. Pelaksanaan

Tahap ini adalah pelaksanaan dari perencanaan yang telah ditetapkan. Dalam siklus pertama ini kegiatan awal yang dilakukan oleh guru adalah memahami kareakteristik siswa dan bagaimana cara belajar siswa yang menerapkan metode bercerita.

Adapun langkah-langkah pelaksanaan yang dilakukan sesuai dengan metode bercerita adalah sebagai berikut:

Kegiatan awal:

1) Guru menyiapkan alat peraga yang dibutuhkan. Peneliti menggunakan kartu bercerita dengan ukuran A4 berwarna dengan kata-kata yang tertulis di bagian belakang kartu.

2) Guru mengadakan apersepsi

3) Guru mengajak siswa menyanyikan lagu Asmaul Husna

4) Guru menjelaskan tujuan pembelajaran Kegiatan Inti:

1) Siswa duduk di karpet menghadap guru.

2) Guru mulai bercerita sesuai lembaran yang tersedia

Kegiatan penutup:

1) Guru menyimpulkan hasil cerita

2) Guru bertanya tentang cerita tersebut

3) Guru menanyakan arti asmaul husna yang dijelaskan berdasarkan cerita

c. Observasi dan Evaluasi 
Pengamatan atau observasi dilakukan oleh guru pendamping sebagai mitra kolaborator yang berfungsi sebagai pencatat semua aktivitas yang dilakukan guru dan siswa. Siklus pertama diakhiri dengan tes (tanya jawab). Berdasarkan hasil observasi, catatan lapangan dan hasil tes maka siklus berikutnya dapat dilaksanakan.

d. Refleksi

Selama menelitian dilaksanakan, hasilnya dianalisis dan dikaji keberhasilan dan kegagalannya. Data yang diperoleh pada proses belajar mengajar dianalisis. Bila ada kekurangan maka analisis direfleksikan untuk menentukan tindakan pada siklus 2 untuk mencapai tujuan. Pada siklus berikutnya akan dipilih cerita dengan kata-kata yang lebih mudah dipahami

Tabel 1 Hasil observasi siklus I

\begin{tabular}{|l|l|l|l|}
\hline No & $\begin{array}{l}\text { Aktivitas } \\
\text { Siswa }\end{array}$ & $\begin{array}{l}\text { Jumlah } \\
\text { siswa }\end{array}$ & $\begin{array}{l}\text { Present } \\
\text { asi }\end{array}$ \\
\hline 1 & $\begin{array}{l}\text { Mendengar } \\
\text { kan cerita }\end{array}$ & 13 & $80 \%$ \\
\hline 2 & $\begin{array}{l}\text { Memahami } \\
\text { inti cerita } \\
\text { dan asmaul } \\
\text { husna }\end{array}$ & 10 & $60 \%$ \\
\hline 3 & $\begin{array}{l}\text { Pemahama } \\
\text { n bahasa } \\
\text { yang } \\
\text { dipakai }\end{array}$ & 10 & $60 \%$ \\
\hline
\end{tabular}

Siklus II:

Pelaksanaan siklus II ini adalah perbaikan dari hasil refleksi yang telah dilakukan pada siklus I. Pelaksanaannya sebagai berikut:

a. Perencanaan

Langkah-langkah yang harus dilakukan dalam tahap perencanaan oleh peneliti bersama guru menyiapkan perangkat pembelajaran. Kemudian dilanjutkan dengan menyiapkan instrument test berupa soal test unjuk kerja penilaiannya. Instrumen non test berupa lembar panduan observasi untuk mengamati aktifitas siswa dan kinerja guru dalam proses pembelajaran. Pada tahap ini dilakukan perubahan sesuai dengan hasil siklus I. Dalam siklus II dipilih kalimatkalimat yang lebih sederhana sehingga lebih mudah dipahami.

b. Pelaksanaan

Tahap ini adalah pelaksanaan dari perencanaan yang telah ditetapkan. Dalam siklus pertama ini kegiatan awal yang dilakukan oleh guru adalah memahami karakteristik siswa dan bagaimana cara belajar siswa yang menerapkan metode bercerita. Adapun langkah-langkah pelaksanaan yang dilakukan sesuai dengan metode bercerita adalah sebagai berikut: Kegiatan awal:

1) Guru menyiapkan alat peraga yang dibutuhkan.

2) Guru mengadakan apersepsi

3) Guru mengajak siswa menyanyikan lagu Asmaul Husna

4) Guru menjelaskan tujuan pembelajaran

Kegiatan Inti:

1) Siswa duduk di karpet menghadap guru.

2) Guru mulai bercerita sesuai lembaran yang tersedia

Kegiatan penutup:

1) Guru menyimpulkan hasil cerita

2) Guru bertanya tentang cerita tersebut

3) Guru menanyakan arti asmaul husna yang dijelaskan berdasarkan cerita

c. Observasi dan Evaluasi

Pengamatan atau observasi dilakukan oleh teman sejawat sebagai mitra kolaborator yang berfungsi sebagai pencatat semua aktivitas yang dilakukan guru dan siswa. Siklus pertama diakhiri dengan tes (tanya jawab). Berdasarkan hasil observasi, catatan lapangan dan hasil tes maka siklus berikutnya dapat dilaksanakan.

d. Refleksi

Selama menelitian dilaksanakan, hasilnya dianalisis dan dikaji keberhasilan 
dan kegagalannya. Data yang diperoleh pada proses belajar mengajar dianalisis. Apabila hasil siklus 2 ada kekurangan pada direfleksikan untuk menentukan tindakan pada siklus selanjutnya.

Tabel 2 Hasil observasi siklus II

\begin{tabular}{|l|l|l|l|}
\hline No & $\begin{array}{l}\text { Aktivitas } \\
\text { Siswa }\end{array}$ & $\begin{array}{l}\text { Jumlah } \\
\text { Siswa }\end{array}$ & $\begin{array}{l}\text { Presen } \\
\text { tasi }\end{array}$ \\
\hline 1 & $\begin{array}{l}\text { Mendengark } \\
\text { an cerita }\end{array}$ & 14 & $90 \%$ \\
\hline 2 & $\begin{array}{l}\text { Memahami } \\
\text { inti cerita } \\
\text { dan asmaul } \\
\text { husna }\end{array}$ & 12 & $80 \%$ \\
\hline 3 & $\begin{array}{l}\text { Pemahaman } \\
\text { bahasa yang } \\
\text { dipakai }\end{array}$ & 12 & $80 \%$ \\
\hline
\end{tabular}

Dari kedua siklus tersebut peneliti membandingkan kedua hasilnya sebagai berikut:

Tabel 3 Perbandingan Hasil observasi siklus I dan II

\begin{tabular}{|l|l|l|l|}
\hline No & Aktivitas Siswa & $\begin{array}{l}\text { Siklus } \\
\text { I }\end{array}$ & $\begin{array}{l}\text { Siklus } \\
\text { II }\end{array}$ \\
\hline 1 & $\begin{array}{l}\text { Mendengarkan } \\
\text { cerita }\end{array}$ & $80 \%$ & $90 \%$ \\
\hline 2 & $\begin{array}{l}\text { Memahami inti } \\
\text { cerita dan } \\
\text { asmaul husna }\end{array}$ & $60 \%$ & $80 \%$ \\
\hline 3 & $\begin{array}{l}\text { Pemahaman } \\
\text { bahasa yang } \\
\text { dipakai } 60 \%\end{array}$ & $80 \%$ \\
\hline
\end{tabular}

Diagram 1 Perbandingan Hasil observasi siklus I dan I

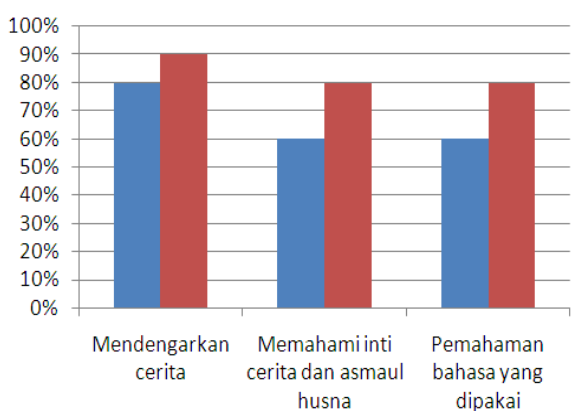

Pada siklus I terdapat peningkatan kemampuan mendengarkan cerita sebesar $80 \%$ dan kemampuan memahami inti cerita dan asmaul husna sebesar $60 \%$ serta pemahaman bahasa yang dipakai sebesar $60 \%$. Pada siklus II terdapat peningkatan kemampuan mendengarkan cerita sebesar 90\% dan kemampuan memahami inti cerita dan asmaul husna sebesar $80 \%$ serta pemahaman bahasa yang dipakai sebesar $80 \%$. Terjadi peningkatan pada siklus II setelah ada perbaikan dalam pembelajaran mengenalkan asmaul husna.

\section{Simpulan}

Dalam penelitian ini terdapat peningkatan kemampuan mendengarkan cerita sebesar $90 \%$ dan kemampuan memahami inti cerita dan asmaul husna sebesar $80 \%$ serta pemahaman bahasa yang dipakai sebesar $80 \%$ sehingga dapat disimpulkan bahwa pengenalan asmaul husna dengan metode bercerita mudah dipahami oleh anak usia dini dibandingkan hanya mengenal atinya saja. Jika pengenalan Asmaul Husna diberikan sejak usia dini, hal ini akan menumbuhkan kecintaan kepada Allah SWT sebagai pemilik dan pencipta seluruh alam ini. Pemilihan teknik bercerita akan mudah diterima oleh siswa. Namun untuk memilih cerita yang tepat, guru dan orang tua harus memilih cerita yang tepat sesuai dengan usia dan tingkat pemahaman anak.

\section{DAFTAR PUSTAKA}

Al Qudsy, Muhaimin. dan Nurhidayah, Ulfah. (2010) Mendidik Anak Lewat Dongeng. Yogyakarta: Madania. 
Arabi, Ibnu. (2015). Rahasia Asmaul Husna: Mengungkap 99 Nama Allah. Jakarta: Turos.

Arikunto, Suharsimi. (2017) Penelitian Tindakan Kelas. Jakarta: Bumi Aksara

El Qudsy, Hasan. (2014) The Miracle of 99 Asmaul Husna. Surakarta: Ziyad Book.

Fadlilah, Muhammad. (2012) Desain Pembelajaran PAUD: Tinjauan Teoritik dan Praktik. Yogyakarta: Ar Ruzz Media.

Gunarti, Linda.dkk (2008). Metode Pengembangan Perilaku dan Kemampuan Dasar Anak Usia Dini, Jakarta: Ute.

Ihsan, Nurul dan Yulianti, Rani. (2007) Asmaul Husna for Kids. Bandung: Oase Mata Air Makna.
Montolulu, dkk. (2008). Bermain dan Permainan Anak. Jakarta: Ute

Santrock, John W. (2009). Life Span Development Perkembangan masa hidup. Jakarta.

Suyadi dan Ulfah, Maulidya. (2013), Konsep Dasar Paud, Bandung: PT Remaja Rosdakarya

Zulfitria. Rahmatunnisa, Sriyanti. Khanza.Mutia (2021). Penggunaan Metode Bercerita Dalam Pengembangan Kemampuan Kognitif Pada Anak Usia Dini. Jakarta: Yaa Bunayya : Jurnal Pendidikan Anak Usia Dini vol 5. Hal 53-60

https://jurnal.umj.ac.id/index.php/YaaBuna yya/article/view/9300 
Upaya Mengenalkan Asmaul Husna Melalui Metode Bercerita Pada Anak Usia Dini

Rausyan Fikr. Vol. 17 No.1 Maret -No.2 September 2021. ISSN. 1979-0074 e-ISSN. $9772580594187 \mid 62$ 